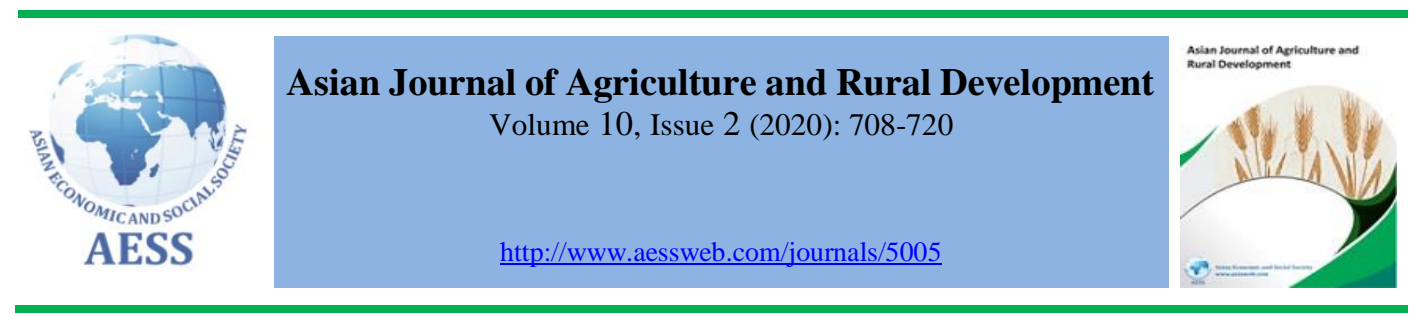

\title{
GROWTH OPTIMA AND SUPPLY-CHAIN OF THE WALNUT CROP IN INDIA
}

\author{
Bakhtaver \\ Hassan $^{\mathrm{a}}$, \\ Mahua \\ Bhattacharjee $^{\mathrm{b}}$, \\ Shabir A Wani ${ }^{\mathrm{c}}$
}

a Visiting Faculty and Research Scholar; Amity School of Economics, Amity University, Noida, Uttar Pradesh, India

b Professor; Amity School of Economics, Amity University, Noida, Uttar Pradesh, India

${ }^{\mathrm{c}}$ Professor and Head; Department of Agricultural

Economics and Horti-business Management, Skuast-K,

Shalimar, Srinagar, Jammu and Kashmir, India

- bakhtaverbaigh@gmail.com,

bakhtaver.hassan@student.amity.edu (Corresponding author)

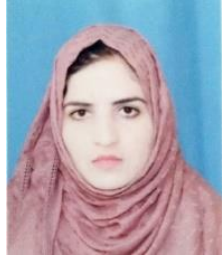

Corresponding author

\section{ARTICLE HISTORY: \\ Received: 31-Mar-2020 \\ Accepted: 01-Aug-2020 \\ Online Available: $14-$ Sep- 2020}

\section{Keywords:}

Marketing-efficiency, variability,

Walnut,

Marketing-margin,

Marketing-cost,

Price-spread

\begin{abstract}
This paper intends to study the Spatio-temporal growth of the walnut crop in Jammu \& Kashmir, which holds a monopoly in walnut production in India. It also aims to assess the efficiency of the existing marketing channels of the walnut-crop in the region. A multi-stage random selection technique was used to collect primary data from three major walnut producing districts to identify the existing marketing channels and estimate their respective efficiencies. Compound-Annual-Growth-rate and Cuddy-Della-Valle index was used to estimate the growth of the walnut crop. Shepherd's Marketing Efficiency Index was used to estimate the marketing efficiencies of the channels involved in the marketing of the crop. This paper found out very-high variability and slow growth in acreage, very-high variability, and high growth in production as well as in yield-per-hectare of the walnut crop.
\end{abstract}

\section{Contribution/ Originality}

The paper provides a comprehensive picture of the variability of the crop in India, which sets a pathway for future researches in the concerned subject. In addition, the paper encourages the use of the most efficient marketing channel for the crop, which will significantly benefit the farmers of the area.

DOI: 10.18488/journal.ajard.2020.102.708.720

ISSN(P): 2304-1455/ ISSN(E): 2224-4433

How to cite: Bakhtaver Hassan, Mahua Bhattacharjee and Shabir A Wani (2020). Growth optima and supply-chain of the walnut crop in India. Asian Journal of Agriculture and Rural Development, $10(2), 708-720$.

() 2020 Asian Economic and Social Society. All rights reserved. 


\section{INTRODUCTION}

Walnut in India is one of the most important horticultural crops being exported to nearly 70 countries generating nearly 10 million USD (778 million INR) annually. Across the globe, India is ranked sixth in terms of acreage under walnut and eight in terms of walnut production, thus being one of the major contributors in walnut cultivation. The production of walnut crops has increased from 185 thousand metric tonnes in 2000-01 to 299 thousand metric tonnes in 2017-18, while the area has increased from 75 thousand hectares to 108 thousand hectares during the same time (Horticulture at a Glance, 2018).

Walnut in India is usually grown in four major states- Jammu \& Kashmir, Himachal Pradesh, Uttarakhand, and Arunachal Pradesh. Jammu \& Kashmir alone contributes over 95 percent of the total production in the country from over 85 percent of the area (Figure 1). Out of the total 108 thousand hectares under walnut cultivation in India, 89 thousand hectares fall in the Union Territory of Jammu and Kashmir. In terms of production, out of the total 299 thousand metric tonnes produced in the country, 275 thousand metric tonnes were produced in Jammu and Kashmir, alone (Horticulture at a Glance, 2018). Figure 1 indicates the importance of Jammu and Kashmir in walnut cultivation of the country. Over the years, the production of walnuts in Jammu and Kashmir is substantially higher than the other states.

The average productivity of walnut cultivation in India is 2.76 metric tonnes/hectare, while in Jammu and Kashmir, it is 3.08 metric tonnes/hectare. Comparing this with other states like Uttarakhand, Himachal Pradesh, and Arunachal Pradesh, the productivity falls to a meager 1.26 metric tonnes/hectare. Therefore, Jammu and Kashmir enjoy a monopoly in production, acreage, and productivity of walnuts in the country. However, this is extremely low when compared to European and North American counterparts, where transgenic rootstocks have already shown the greatest promise (Britton et al., 2009).

From an agro-climatic perspective, Jammu and Kashmir are divided into three distinct zonestemperate, sub-temperate, and arid, while the fourth zone (arid) is now a separate Union TerritoryLadakh (Khursheed and Taufeeq, 2019). Each zone has a distinguished cropping pattern with a certain number of commonly grown crops that are unique to each zone. For instance, Jammu is known for the cultivation of Basmati Rice, Wheat while Kashmir is famous for Apples, Pear, Cherries, and Saffron (Kumar et al., 2013; Hanan, 2015; Qadri, 2018). However, walnut is the only major horticultural crop that is cultivated in all the agro-climatic zones of the Union Territory. From Kashmir Valley, the major districts of walnut production are Anantnag, Kulgam, Kupwara, Shopian, Baramulla, Pulwama, and Jammu; the major districts are Doda, Reasi, Rajouri, Kishtwar, Kathua, Udhampur, and Ramban. Kashmir Valley produces 60 percent of the product while the rest comes from Jammu; however, the growth rate in production, as well as acreage under walnut cultivation, is growing faster in Jammu as compared to Kashmir valley, thus moving neck to neck (Malhotra and McNeil, 2009). The past tends witnessed an actual fall in walnut production as the walnut trees have faced continued degradation and ineffective policies, which is seen in Jammu and Kashmir too (Shigaeva and Darr, 2020) 


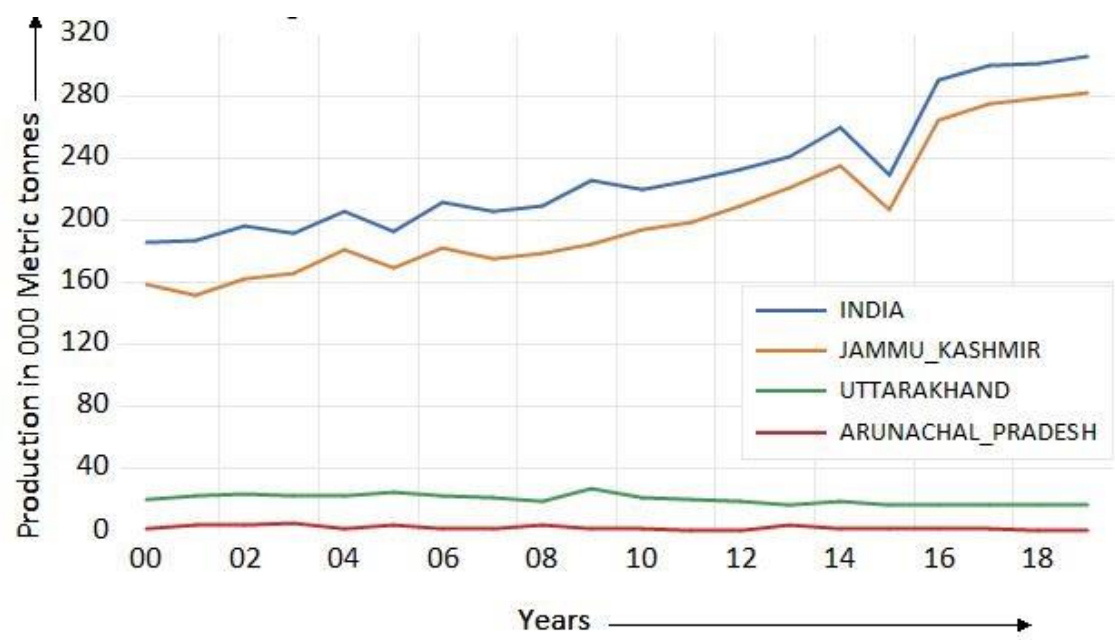

\section{Figure 1: Walnut production across states}

Source: Horticulture at a Glance, National Horticulture Board, India

The export of walnut from Jammu \& Kashmir to other countries is over 95 percent, which is substantial for its agricultural economy. The Walnut industry, thus, provides excelling opportunities to the farmers in the Union Territory with almost no input variable cost while being completely organic (Qammer and Baba, 2018; Sharma and Sumbali, 2014).

\section{OBJECTIVES OF THE STUDY}

1. To analyze the growth and variability of walnut cultivation in the major walnut producing districts of the country, especially in the largest walnut producing state.

2. To identify the marketing channels of the walnut crop and estimate the efficiency of each marketing channel.

\section{RESEARCH METHODOLOGY}

This study was based on the data collected in February 2020, from walnut farmers from three Districts- Anantnag, Shopian, and Kulgam, which were purposively selected as they produce nearly 55 percent of the total walnuts in Jammu and Kashmir, India. The selection of three districts from the Union Territory enables us to fully analyse the spatial and temporal growth, as well as identify the issues in the walnut industry of the country.

A multi-stage random selection technique was used in data collection. In the first stage, one block was selected from each district. In the second stage, three villages were selected from each block of the district, and in the final stage, five farmers were selected from each selected village of the block. From Kulgam District, Devsar block was selected from which three random villages were selected; namely, Hablish, Gangdaar, and Akhal were selected. From District Anantnag, Shangus block was selected. In Shangus block, villages, namely Shangus, Kihirbal, and Nowgam, were selected. Finally, from District Shopian, Zainapora block was selected in this block; villages, namely Hyderpora, Zainapora, and Bongam were selected.

Batamallu, one of the biggest markets in the Union Territory, was purposively selected as $60 \%$ of the walnut crop is sold here. Unregulated local district markets of the three districts were studied accordingly. 
Table 1: Walnut growers with a number of walnut trees

\begin{tabular}{lc}
\hline Farmer & Number of farmers \\
\hline Small (<50 Trees) & 23 \\
Medium (50-100 Trees) & 14 \\
Large ( $>100$ Trees) & 8 \\
TOTAL & 45 \\
\hline
\end{tabular}

Secondary Data was collected from the Directorate of Horticulture, Jammu \& Kashmir, National Horticultural Board, Economic Survey, 2018-19 and Readers' Digest, Jammu \& Kashmir. The secondary data was used to estimate the Compound Annual Growth Rate and Cuddy-Della-ValleVariability Index. Primary Data was collected to identify the existing marketing channels of walnut crops and estimate the marketing cost, marketing margin, marketing efficiency using Marketing Efficiency Index, and Shepherd's Marketing Index.

\section{METHODOLOGY}

Production variability may arise due to the variability in area, yield and/or interaction between area and yield. Variability in yield is the main source of production instability, and therefore, CuddyDella-Valle index was used. Cuddy-Della Valle index is a measure of regional variability in timeseries data. It is an improvement over the simple coefficient of variations, as it corrects the coefficient of variation, which is usually over-estimated in the simple coefficient of variation (Deb et al., 1999). The Cuddy-Della-Valle-Index was estimated on the secondary data for the time-trend of 2004-2017.

The formula for Cuddy-Della-Valle index is:

$$
C V=C V^{*} \sqrt{\left(1-R^{2}\right)}
$$

Where CV is the Cuddy-Della-Valle index, $C V^{*}$ is the simple coefficient of variation in percent, $R^{2}$ is the coefficient of determination from a time-trend regression analysis adjusted by the number of degrees of freedom.

$$
\text { Coefficent of Variation, } C V^{*}=\frac{\text { Standard Deviation }}{\text { Mean }} \times 100
$$

Compound Annual Growth Rate was estimated to assess the growth in the area, production, and yield per hectare of walnut in Jammu and Kashmir, India. Compound Annual Growth Rate is the rate of return of investment for overtime (Naqash, 2015; Wani et al., 2014).

The formula for Compound Annual Growth Rate is:

$$
C A G R=\left(\frac{V_{\text {final }}}{V_{\text {begin }}}\right)^{\frac{1}{t}}-1
$$

Where CAGR is Compound Annual Growth Rate, $V_{\text {final }}$ is the value of the area, production, and yield per hectare at the end, here in 2016-17 and $V_{\text {begin }}$ is the value of area, production and yield per hectare at the beginning of 2004-05 and " $t$ " is the time period from 2004 to 2017.

\subsection{Marketing channels and efficiency model}

To identify the channels involved in the marketing efficiency of the supply-chain of walnut in Jammu and Kashmir, mapping was done. In the survey of three selected districts, three main channels were identified through which walnut crop was marketed. These main channels are: 
1. Channel I: Producer-Retailer-Consumer

2. Channel II: Producer- Wholesaler- Retailer-Consumer

3. Channel III: Producer-Arhatia (Middlemen)-Wholesaler- Retailer-Consumer

The marketing Cost of Walnut was calculated by estimating the cost incurred in the process of marketing of the product from harvesting until it reached the consumer. It included the transportation cost, marketing fee, labour charges during transportation, packaging cost like gunny bags, cartons. Marketing Margin is the profit or the revenue earned by each actor at a particular stage of the marketing channel (Dastagiri et al., 2012). Marketing Margin at different stages of the chains was calculated using the formula:

Marketing Margin of each actor:

$$
M M_{i}=S P_{i}-\left(P P_{i}+M C_{i}\right)
$$

Where $M M_{i}$ is the marketing margin for " $i$ th" actor, $S P_{i}$ is the selling price of the " $i$ th" actor, $P P_{i}$ is the purchasing price of the " $i$ th" actor and $M C_{i}$ is the marketing cost incurred by "ith" actor.

Producers' share is the amount that the producer receives to the total amount paid for the commodity (Dastagiri et al., 2012; Gachena and Kebebew, 2014; Mohapatra et al., 2018). Producers' share in consumer's rupee was calculated as follows:

$$
\text { Producers'Share }=\frac{\text { Producers }{ }^{\prime} \text { Price }}{\text { Consumers'Price }} \times 100
$$

Shepherd suggested that the ratio of the total price paid by the consumer to the total marketing cost incurred at various stages along the marketing channel may be used as a major of efficiency. The higher the ratio, the higher will be the marketing efficiency of the channel. This method eliminates the problem of measurement of value-added (Sharma and Tungoe, 2011). Since walnut processing has minimum value addition along the marketing channels; therefore, Shepherds' Marketing Efficiency Index was used to estimate the overall marketing efficiency of the three marketing chains identified. The formula for Shepherd's Marketing Efficiency Index is:

$$
\text { Shepherd's Marketing Index }=\frac{\text { Consumer's Price }}{\text { Total Marketing Cost }}-1
$$

To ensure the marketing efficiency of the channels is measured accurately, this concept was also used to incorporate both the marketing margin as well as the marketing cost of the channels. Marketing Efficiency was also calculated through simple Marketing Efficiency Index, the formula for which is:

$$
\text { Marketing Efficiency Index }=\frac{\sum_{i=1}^{i=n} M M_{i}}{\sum_{i=i}^{i=n} M C_{i}}
$$

Where, $M M_{i}$ is the marketing efficiency of "ith" actor and $M C_{i}$ is the marketing cost of "ith" actor in the supply chain, the formula therefore represents the total marketing efficiency of the supply chain by including the total marketing margin and cost involved in the chain.

\section{RESULTS AND DISCUSSION}

\section{Part I: Growth and variability of walnut in Jammu and Kashmir}

Based on the secondary data from the Department of Finance, Jammu \& Kashmir, the compound annual growth rate of the area, production, and yield per hectare was calculated from 2004 to 2017 for all the major walnut producing districts of the Union Territory (Table 2). 
Table 2: Growth and variability in area, production and yield of walnut from 2004-17

\begin{tabular}{lccccccccc}
\hline & \multicolumn{3}{c}{ Area } & \multicolumn{3}{c}{ Production } & \multicolumn{3}{c}{ Yield per hectare } \\
& CAGR & $\mathbf{C V}$ & $\mathbf{R}^{\mathbf{2}}$ & CAGR & $\mathbf{C V}$ & $\mathbf{R}^{\mathbf{2}}$ & $\mathbf{C A G R}$ & $\mathbf{C V}$ & $\mathbf{R}^{\mathbf{2}}$ \\
\hline Anantnag & 3.13 & 12.23 & 0.91 & 11.18 & 25.42 & 0.87 & 7.89 & 9.23 & 0.91 \\
Baramulla & 1.12 & 23.52 & 0.89 & 4.15 & 32.42 & 0.96 & 3.55 & 37.53 & 0.85 \\
Budgam & 0.53 & 38.52 & 0.81 & 5.52 & 23.42 & 0.91 & 5.23 & 10.24 & 0.82 \\
Kulgam & 1.72 & 18.63 & 0.92 & 9.11 & 11.52 & 0.95 & 7.23 & 16.44 & 0.84 \\
Kupwara & 1.25 & 21.52 & 0.9 & 9.52 & 16.34 & 0.85 & 6.64 & 18.23 & 0.94 \\
Shopian & 2.14 & 29.23 & 0.95 & 8.31 & 26.23 & 0.89 & 4.39 & 19.42 & 0.91 \\
Pulwama & 1.36 & 9.23 & 0.87 & 5.13 & 15.23 & 0.81 & 6.92 & 21.59 & 0.91 \\
Ganderbal & -0.12 & 27.34 & 0.96 & 6.42 & 13.76 & 0.92 & 4.35 & 22.24 & 0.97 \\
Doda & 0.9 & 32.52 & 0.91 & 10.63 & 21.42 & 0.89 & 5.23 & 12.14 & 0.92 \\
Kishtwar & 2.65 & 21.51 & 0.95 & 9.57 & 9.23 & 0.95 & 9.52 & 9.44 & 0.89 \\
Reasi & 1.4 & 8.52 & 0.85 & 9.24 & 25.24 & 0.87 & 6.12 & 11.42 & 0.82 \\
Ramban & 1.5 & 21.53 & 0.89 & 4.14 & 29.23 & 0.96 & 2.63 & 25.52 & 0.91 \\
Kathua & 0.92 & 15.53 & 0.9 & 5.31 & 12.35 & 0.84 & 8.51 & 26.42 & 0.98 \\
Udhampur & 1.54 & 29.26 & 0.92 & 5.23 & 35.42 & 0.82 & 6.2 & 15.94 & 0.91 \\
Poonch & 0.24 & 31.52 & 0.91 & 8.91 & 13.53 & 0.95 & 5.2 & 11.52 & 0.82 \\
Rajouri & 1.57 & 26.24 & 0.93 & 8.63 & 21.43 & 0.85 & 5.41 & 10.53 & 0.95 \\
Jammu and Kashmir & 1.38 & 22.93 & 0.90 & 7.56 & 20.76 & 0.89 & 6.13 & 17.27 & 0.90 \\
India & 1.21 & 23.34 & 0.87 & 6.93 & 20.41 & 0.87 & 6.13 & 17.45 & 0.90 \\
\hline
\end{tabular}

Source: Computed by authors

Ecostat Readers' Digest, Department of Finance, Jammu \& Kashmir.

During this period, the area under walnut cultivation increased from 74,894 hectares in 2004 to 89431 hectares in 2017, with an annual compound growth rate of 1.38 percent. However, in production, the Union Territory saw a compound growth rate of 7.56 percent during the same time, increasing from 100596 Metric tonnes in 2004 to 260308 Metric tonnes in 2017 (Ecostat, Readers' Digest, 2018).

Based on the compound annual growth rate, districts are classified into four major categories.

1. Category A- High Compound Annual Growth Rate- > 5\%

2. Category B- Moderate Compound Annual Growth Rate - 2-5\%

3. Category C-Slow Compound Annual Growth Rate- $0-2 \%$

4. Category D-Negative Compound Annual Growth Rate- <0 \%

Similarly, based on the Cuddy-Della-Valle variability index, these districts are classified into four major categories in terms of the percentage of variability:

1. Category P- Low Variability- <5\%

2. Category Q- Moderate Variability $-5-10 \%$

3. Category R- High Variability- $10-20 \%$

4. Category S- Very High Variability- $>20 \%$

From the development point of, "A\&P" showcases a high growth rate and low variability, which is the most desirable situation and "D\&S" showcasing negative growth rate and very high variability is the worst situation.

Table 2 represents the growth rate and variability of all the three parameters- area, production, and yield per hectare of the walnut crop. In the area, the growth rate in the Union Territory is slow (1.38 percent), which is slightly higher than the national growth rate of 1.21 percent. At the district level, only Ganderbal District is the major outlier witnessing a negative growth rate during the period 
(2004-17). In terms of production and yield per hectare, the majority of the districts witness a highgrowth rate of above 5 percent. Considering the slow growth in acreage, this high growth rate in production is crucial for the farmers as well as the overall development of the crop. Even the overall growth rate in production and yield per hectare is above 5 percent, which indicates that walnuts are still preferable fruit-bearing crops for the farmers in Jammu \& Kashmir, India (see Table 2).

Table 3 shows the relationship between the growth rate and variability of each district under study. In the area, all the districts show slow to moderate growth, except for District Ganderbal. The major cause of falling acreage in the District under walnut crop is the long-gestation period and the consequent aging of the trees while there are no major new walnut orchards established. Second, the demand for walnut timber in furniture in the country is rising, which has resulted in rapid and wholesome cutting down of the walnut trees. The third is the large area required for each walnut tree, which the farmer feels leads to greater opportunity cost, only based on mere speculation. Variability in the area is on the higher side in 90 percent of the districts; only Pulwama and Reasi District show moderate variability of under 10 percent. But there is no conclusive evidence which points out at this lower variability in these two districts compared to the rest. Overall, the high variability and low growth rate are worrisome for the overall development and expansion of the walnut crop in the region (Deb et al., 1999).

Table 3: District wise growth and variability characteristics of area, production and yield from 2004-17

\begin{tabular}{|c|c|c|c|c|}
\hline No. & Districts & Area & Production & Yield \\
\hline 1 & Anantnag & $\begin{array}{l}\text { Moderate Growth and } \\
\text { High Variability }\end{array}$ & $\begin{array}{l}\text { High Growth and } \\
\text { Very High } \\
\text { Variability }\end{array}$ & $\begin{array}{l}\text { High Growth and } \\
\text { Moderate Variability }\end{array}$ \\
\hline 2 & Baramulla & $\begin{array}{l}\text { Slow growth and Very } \\
\text { High Variability }\end{array}$ & $\begin{array}{c}\text { Moderate Growth } \\
\text { and Very High } \\
\text { Variability }\end{array}$ & $\begin{array}{l}\text { High Growth and Very } \\
\text { High Variability }\end{array}$ \\
\hline 3 & Budgam & $\begin{array}{l}\text { Slow growth and Very } \\
\text { High Variability }\end{array}$ & $\begin{array}{l}\text { High Growth and } \\
\text { Very High } \\
\text { Variability }\end{array}$ & $\begin{array}{c}\text { High Growth and High } \\
\text { Variability }\end{array}$ \\
\hline 4 & Kulgam & $\begin{array}{l}\text { Slow growth and High } \\
\text { Variability }\end{array}$ & $\begin{array}{l}\text { High Growth and } \\
\text { High Variability }\end{array}$ & $\begin{array}{c}\text { High Growth and Very } \\
\text { High Variability }\end{array}$ \\
\hline 5 & Kupwara & $\begin{array}{l}\text { Slow growth and Very } \\
\text { High Variability }\end{array}$ & $\begin{array}{l}\text { High Growth and } \\
\text { High Variability }\end{array}$ & $\begin{array}{l}\text { High Growth and High } \\
\text { Variability }\end{array}$ \\
\hline 6 & Shopian & $\begin{array}{l}\text { Moderate Growth and } \\
\text { Very High Variability }\end{array}$ & $\begin{array}{c}\text { High Growth and } \\
\text { Very High } \\
\text { Variability }\end{array}$ & $\begin{array}{c}\text { Moderate Growth and } \\
\text { High Variability }\end{array}$ \\
\hline 7 & Pulwama & $\begin{array}{c}\text { Slow growth and } \\
\text { Moderate Variability }\end{array}$ & $\begin{array}{l}\text { High Growth and } \\
\text { High Variability }\end{array}$ & $\begin{array}{c}\text { High Growth and Very } \\
\text { High Variability }\end{array}$ \\
\hline 8 & Ganderbal & $\begin{array}{c}\text { Negative Growth and Very } \\
\text { High Variability }\end{array}$ & $\begin{array}{l}\text { High Growth and } \\
\text { High Variability }\end{array}$ & $\begin{array}{l}\text { High Growth and Very } \\
\text { High Variability }\end{array}$ \\
\hline 9 & Doda & $\begin{array}{l}\text { Slow growth and Very } \\
\text { High Variability }\end{array}$ & $\begin{array}{c}\text { High Growth and } \\
\text { Very High } \\
\text { Variability }\end{array}$ & $\begin{array}{c}\text { High Growth and High } \\
\text { Variability }\end{array}$ \\
\hline 10 & Kishtwar & $\begin{array}{l}\text { Moderate Growth and } \\
\text { Very High Variability }\end{array}$ & $\begin{array}{c}\text { High Growth and } \\
\text { Moderate } \\
\text { Variability }\end{array}$ & $\begin{array}{l}\text { High Growth and } \\
\text { Moderate Variability }\end{array}$ \\
\hline 11 & Reasi & $\begin{array}{l}\text { Slow growth and } \\
\text { Moderate Variability }\end{array}$ & $\begin{array}{c}\text { High Growth and } \\
\text { Very High } \\
\text { Variability }\end{array}$ & $\begin{array}{c}\text { High Growth and High } \\
\text { Variability }\end{array}$ \\
\hline 12 & Ramban & Slow Growth and Very & Moderate Growth & Moderate Growth and \\
\hline
\end{tabular}




\begin{tabular}{|c|c|c|c|c|}
\hline & & High Variability & $\begin{array}{l}\text { and Very High } \\
\text { Variability }\end{array}$ & Very High Variability \\
\hline 13 & Kathua & $\begin{array}{c}\text { Slow Growth and Very } \\
\text { High Variability }\end{array}$ & $\begin{array}{l}\text { High Growth and } \\
\text { High Variability }\end{array}$ & $\begin{array}{c}\text { High Growth and Very } \\
\text { High Variability }\end{array}$ \\
\hline 14 & Udhampur & $\begin{array}{c}\text { Slow Growth and Very } \\
\text { High Variability }\end{array}$ & $\begin{array}{c}\text { High Growth and } \\
\text { Very High } \\
\text { Variability }\end{array}$ & $\begin{array}{c}\text { High Growth and High } \\
\text { Variability }\end{array}$ \\
\hline 15 & Rajouri & $\begin{array}{c}\text { Slow Growth and Very } \\
\text { High Variability }\end{array}$ & $\begin{array}{l}\text { High Growth and } \\
\text { Very High } \\
\text { Variability }\end{array}$ & $\begin{array}{c}\text { High Growth and High } \\
\text { Variability }\end{array}$ \\
\hline \multirow[t]{3}{*}{16} & Poonch & $\begin{array}{c}\text { Slow Growth and Very } \\
\text { High Variability }\end{array}$ & $\begin{array}{l}\text { High Growth and } \\
\text { High Variability }\end{array}$ & $\begin{array}{c}\text { High Growth and High } \\
\text { Variability }\end{array}$ \\
\hline & $\begin{array}{l}\text { Jammu } \\
\text { and } \\
\text { Kashmir }\end{array}$ & $\begin{array}{c}\text { Slow Growth and Very } \\
\text { High Variability }\end{array}$ & $\begin{array}{l}\text { High Growth and } \\
\text { Very High } \\
\text { Variability }\end{array}$ & $\begin{array}{c}\text { High Growth and High } \\
\text { Variability }\end{array}$ \\
\hline & India & $\begin{array}{c}\text { Slow Growth and Very } \\
\text { High Variability }\end{array}$ & $\begin{array}{c}\text { High Growth and } \\
\text { Very High } \\
\text { Variability }\end{array}$ & $\begin{array}{c}\text { High Growth and High } \\
\text { Variability }\end{array}$ \\
\hline
\end{tabular}

Source: Authors' analysis

In terms of production, the growth rate is high in all the districts except Baramulla where the growth rate is moderate, surprisingly, as the District is one of the leading horticultural districts of the Union Territory. But 10 out of 16 districts show very high variability in production while only one District, Kishtwar shows moderate variability. In terms of yield per hectare, six districts show very high variability, 9 show high variability, while only one shows moderate variability. In terms of growth rate, the majority of the districts show high-growth, which runs in sync with the overall increase in yield of walnut in the country during the period. However, the high to very high variability in the majority of the districts in both production, as well as yield per hectare, is worrisome.

Overall, the area under walnut crop is increasing at a slow-rate, but the production and yield per hectare are increasing at a relatively healthier rate. But the worrisome picture is the very high variability in terms of acreage and production of the crop and high variability in the yield per hectare of the crop.

\section{Part II- Market efficiency of the walnut crop}

While the production and yield per hectare of walnut are increasing at a considerably good rate, the variation in production among the different farmer categories is not so significant. Yield per tree for small farmers of less than 50 trees is 0.0677 tonnes/tree; it is 0.074 tonnes/tree for medium farmers and large farmers, yield per tree is 0.068 tonnes/tree (see Table 4). The lower variation in yield per tree is majorly due to no inputs used by either of the farmers. In the three districts where the survey was conducted, each farmer was of the same view that these walnut trees need no input supplies per year, implying that the input variable cost like the use of fertilizers, irrigation, fungicides is zero. Therefore, to substantiate the facts, walnut cultivation in Jammu \& Kashmir, India is completely organic with no use of fertilizers, chemicals, and other synthetic materials. However, the lack of proper government support and adequate marketing strategies, the crop is still marketed through ordinary channels, which impacts the growth of the crop overall. 
Table 4: Marketed surplus and disposal through different channels

\begin{tabular}{lccccc}
\hline & $\begin{array}{c}\text { Production } \\
\text { in tonnes }\end{array}$ & $\begin{array}{c}\text { Marketed } \\
\text { surplus in } \\
\text { tonnes }\end{array}$ & \multicolumn{2}{c}{ Disposal through (in tonnes) } \\
& & & Channel I & Channel II & Channel III \\
\hline Small $(20)^{*}$ & 1.344 & 1.29 & $0.122(9.4)$ & $0.357(27.67)$ & $0.811(62.86)$ \\
Medium $(60) *$ & 4.464 & 4.362 & $0.479(11)$ & $1.352(31.01)$ & $2.531(58.02)$ \\
Large $(100)^{*}$ & 7.884 & 7.725 & $1.236(16.10)$ & $2.723(35.25)$ & $3.766(48.75)$ \\
Total & 13.69 & 13.37 & $1.83(13.72)$ & $4.43(33.13)$ & $7.1(53.13)$ \\
\hline
\end{tabular}

The figures in parenthesis indicate the percentages

* indicates the average number of trees

Source: Field survey, 2020

The study revealed that 62.86 percent of the small farmers marketed their harvested crop through Channel III, while this decreased to 58 percent in medium farmers and just 48.75 percent in large farmers. On the contrary, only 9.4 percent of the small farmers marketed their harvest through Channel I, while the percentage increased to 16.10 percent in the large-farmers (see Table 4). Overall, 13.37 percent of the farmers disposed-off their marketed surplus through Channel I, 33.13 percent disposed-off through Channel II, while 53.5 percent disposed-off through Channel III. It is worth noticing that 86.63 percent of the total walnut produced by the farmers passed through the secondary markets to reach the final consumers (see Table 4). It shows that there is an absolute absence of marketing intelligence on the farmer's side, resulting in a higher number of intermediaries in different marketing channels.

\subsection{Price spread under different channels}

The three main channels used in the marketing of the walnut crop in the region showcase that the relationship between the farmer and the other actors involved is wholly based on poor dissemination of marketing information to the farmers. Therefore, the channels witness a rise in the number of actors for marketing the product, which increases the marketing cost as well as the gross marketing margin of the channels. It is consistent with the economic analysis done by Malhotra and McNeil (2009).

\section{Channel I}

The walnut crop in this channel moved from the farmer to the final consumer through the retailer. Therefore, with a lesser number of intermediaries, the producers'/farmer's share in this channel is 75.6 percent of the total price paid by consumers, making it the most efficient marketing channel of the walnut crop in Jammu and Kashmir, India (see Table 5). After the presence of only one major actor in the channel, the marketing cost and the marketing margin incurred are 7.98 percent and 16.42 percent, respectively.

\section{Channel II}

The producer's share in this channel drops to 67.38 percent of the total price paid by the consumer while the marketing cost and the marketing margin rise to 14.36 and 18.26 percent, respectively. The addition of wholesalers to which the farmer sells his produce incurs a marketing cost of 7.24 percent and earns a margin of 5.64 percent (see Table 5). The marketing cost rises on account of the longer chain and the cost incurred in transportation, loading, unloading, and processing of the walnut crop at the wholesale stage. 


\section{Channel III}

Table 5: Marketing cost, marketing margin and price spread of the three channels in USD ${ }^{1}$

\begin{tabular}{lccc}
\hline & Channel I & Channel II & Channel III \\
\hline $\begin{array}{l}\text { Net price received by producer per tonne in } \\
\text { INR }\end{array}$ & $2520(75.6)$ & $2246(67.4)$ & $1982.6(59.48)$ \\
Marketing cost incurred by a producer & $126.67(3.8)$ & $120.67(3.62)$ & $122(3.66)$ \\
$\begin{array}{l}\text { Selling price of producer/purchasing power } \\
\text { of arhatia }\end{array}$ & $2646.67(79.4)$ & $2366.67(71)$ & $2104.67(63.14)$ \\
Marketing cost incurred by arhatia & - & - & $70.67(2.12)$ \\
Marketing margin of arhatia & - & - & $170(5.1)$ \\
$\begin{array}{l}\text { Selling price of arhatia/ purchasing price of } \\
\text { wholesaler }\end{array}$ & - & - & $2345.33(70.36)$ \\
Marketing cost incurred by a wholesaler & - & $241.33(7.24)$ & $246.67(7.4)$ \\
Marketing margin of wholesaler & - & $188(5.64)$ & $241.67(7.25)$ \\
$\begin{array}{l}\text { Selling price of wholesaler/purchasing price } \\
\text { of the retailer }\end{array}$ & - & $2796(83.9)$ & $2833.67(85.01)$ \\
Marketing cost incurred by the retailer & $139.33(4.18)$ & $116.67(3.50)$ & $110(3.3)$ \\
Marketing margin of retailer & $547.33(16.42)$ & $420.67(12.62)$ & $389.67(11.69)$ \\
Selling price of retailer / consumers' price & $3333.33(100)^{2}$ & $3333.33(100)$ & $3333.33(100)$ \\
Total marketing margin & $547.33(16.42)$ & $608.67(18.26)$ & $801.33(24.04)$ \\
Total marketing cost & $266(7.98)$ & $478.67(14.36)$ & $549.33(16.48)$ \\
Producers' share in consumers' rupee & $75.60 \%$ & $67.38 \%$ & $59.48 \%$ \\
\hline
\end{tabular}

Percentages to the total selling price of the products are in parentheses

Source: Authors' analysis based on field survey, 2020

Table 5 reveals that this channel is the most inefficient marketing channel of the walnut crop in the region. The producer's share in this channel drops even further to 59.48 percent. This means that 40.52 percent of the total selling price of the produce goes to other actors in the chain, rendering it inefficient and unsustainable for the farmer. The farm-produce through this channel changes multiple hands from producer to kacha and pakka Arhatia (middle-men), wholesaler, retailer, and finally, the consumer. Each actor earns a substantial amount of marketing margin as well as incurs a certain amount of marketing cost to transportation, grading, loading, unloading, and packing the produce/commodity. For instance, the Arhatia incurs 2.12 percent as marketing cost and charges 5.1 percent as his/her marketing margin.

Similarly, the wholesaler and retailer incur a cost of 7.4 percent and 3.3 percent in moving the walnut crop from the purchasing point to their respective selling destinations. Overall, the total marketing cost and marketing margin in the channel is 16.48 percent and 24.04 percent, respectively (see Table 5). Malhotra and McNeil (2009) had made a similar observation in their analysis of these marketing channels.

Furthermore, 53.5 percent of the farmer's market their walnut crop through Channel III, the most inefficient channel present, while another 33.13 percent market their produce through Channel II, where the marketing cost and marketing margins are on the higher side. Thus, at present, 86.63 percent of the farmers' market their produce through inefficient marketing channels, which eats away the profitability of the farmers involved, as well as hampers the expansion of the crop in the region.

\footnotetext{
${ }^{1} \mathrm{USD}=75 \mathrm{INR}$ at average exchange rate, 2020

${ }^{2}$ Price of walnut at Batamallu Mandi was $3.33 \mathrm{USD} / \mathrm{kg}$
} 


\subsection{Marketing efficiency}

Price Spread across the three marketing channels varies from 24.4 percent in Channel I, 32.62 in Channel II to 40.52 percent in Channel III. The comparison reveals that Channel I is the most efficient marketing channel of the walnut crop in the region and that there is a difference of 15.9 percent between Channel I and Channel III.

Ranking the three channels based on price-spread, producer's share, and marketing cost, Channel I turns out to be the most efficient marketing channel, providing 75.6 percent of the total price paid by the consumer to the farmer. On the other hand, producer's share in Channel II and Channel III is lower at 67.38 percent and 59 percent, respectively, rendering them inefficient from the farmer's perspective.

Surprisingly, Channel III is ranked second in Marketing Efficiency Index with an index of 2.45, while Channel II has an index of 2.27. Channel I shows an index of 3.05, making it highly feasible for the farmers (see Table 6). By Shepherd's Marketing Efficiency, Channel I outperforms the other two channels by quite a margin, having an index of 11.53 , which is higher than the index of the other channels combined. Channel II is ranked a distant second with an index of 5.96, while Channel III ranks third with an index of 5.06. Overall, Channel I is ranked first, while Channel II and Channel III are ranked second and third in the composite marketing efficiency index, respectively.

Table 6: Composite marketing index of the three channels (USD) ${ }^{3}$

\begin{tabular}{|c|c|c|c|c|}
\hline \multirow[b]{2}{*}{ No. } & \multirow[b]{2}{*}{ Particulars } & \multicolumn{3}{|c|}{ Channels } \\
\hline & & I & II & III \\
\hline \multirow{2}{*}{1} & \multirow{2}{*}{ Price Spread (Rank) } & $813.33(24.4)$ & $1087.33(32.62)$ & $1350.67(40.52)$ \\
\hline & & 1 & 2 & 3 \\
\hline \multirow{2}{*}{2} & \multirow{2}{*}{ Producers' Share (Rank) } & $75.60 \%$ & $6738 \%$ & $59 \%$ \\
\hline & & 1 & 2 & 3 \\
\hline \multirow[t]{3}{*}{3} & Marketing Cost (Rank) & 1 & 2 & 3 \\
\hline & Total Score & 3 & 6 & 9 \\
\hline & Mean Score & 1 & 2 & 3 \\
\hline \multirow{2}{*}{4} & \multirow{2}{*}{ Marketing Efficiency Index (Rank) } & 3.05 & 2.27 & 2.45 \\
\hline & & 1 & 3 & 2 \\
\hline \multirow{6}{*}{5} & Shepherds' Marketing Efficiency & 11.53 & 5.96 & 5.06 \\
\hline & Index (Rank) & 1 & 2 & 3 \\
\hline & Total Score & 2 & 5 & 5 \\
\hline & Mean Score & 1 & 2.5 & 2.5 \\
\hline & Total Mean Score & 1 & 2.25 & 2.75 \\
\hline & RANK & 1 & 2 & 3 \\
\hline
\end{tabular}

Source: Author's analysis

Percentages in parentheses

\section{CONCLUSION}

The Walnut crop in India is facing challenges with slow-growth in acreage at the time when the demand is picking up for organic food all over the world. The production and yield per hectare in major walnut producing districts is high, falling in the range between 5-10 percent. One of the unique features of the walnut crop is its almost negligible input cost and completely organic nature. Still, the lower use of technology in terms of hybrid varieties is rendering it highly variable in all the parameters-acreage, production, and yield per hectare. Further, the marketing of the walnut crop through different channels also need considerable revision. Only 13.37 percent of the farmers

${ }^{3} \mathrm{USD}=75 \mathrm{INR}$ at average exchange rate, 2020 
market their products through the most efficient channel present in Jammu and Kashmir. On the flip side, 53.5 percent of farmers prefer the most inefficient channel where the marketing cost and margin are at 40.52 percent. This is directly correlated to the loss of interest of the farmers to pursue walnut cultivation in their farms, which is witnessed in the extremely slow expansion of area under walnut cultivation and very high-variability of the crop in acreage, production and yield per hectare.

On the marketing front, the farmers are forced to market their products through highly inefficient channels on account of poor marketing intelligence, lack of proper market infrastructure, a high number of intermediaries, and lack of government support. At the village level understudy, the information regarding the pricing of walnuts is extremely poor, and there is a wide information gap that the Arhatias(middle-men) exploit to the fullest.

The government, therefore, needs to provide village-level processing units, which would promote the direct sale of the walnut crop from the farmers to the markets and retailers and lead to a reduction of intermediaries in the chain. Emphasis should be laid on scientific research to bring in hybrid varieties of walnut cultivars for higher productivity, early gestation period leading to higher acceptance of the walnut cultivation by the farmers. From a marketing perspective, walnut should be tagged as "organic," which would increase its overall price, and with efficient marketing channels, the farmers would be benefited the most. Therefore, infrastructural development, scientific research and pro-active policy-making would help to enhance productivity, increase acreage and improve marketing of the walnut crop leading to the overall development of the crop as well horticultural sector in Jammu and Kashmir and India.

Funding: This study did not receive any specific financial support.
Competing Interests: The authors declare that they have no competing interests.
Contributors/Acknowledgement: All authors participated equally in designing and estimation of current
research.
Views and opinions expressed in this study are the views and opinions of the authors; the Asian Journal of
Agriculture and Rural Development shall not be responsible or answerable for any loss, damage or liability,
etc. caused in relation to/arising out of the use of the content.

\section{Bibliography}

Dastagiri, M. B., Kumar, B. G., Hanumanthaiah, C. V., Paramsivam, P., Sidhu, R. S., Sudha, M., \& Chand, K. (2012). Marketing efficiency of India's horticultural commodities under different supply chains. Outlook on Agriculture, 41(4), 271-278. doi.org/10.5367/oa.2012.0103.

Deb, U. K., Joshi, P. K., \& Bantilan, M. C. S. (1999). Impact of modern cultivars on growth and relative variability in sorghum yields in India. Agricultural Economics Research Review, 12(2), 84-106.

Gachena, D., \& Kebebew, S. (2014). Analysis of coffee marketing cost and margins in South West, Ethiopia. Journal of Agricultural Research, 3, 165-173.

Ecostat, Reader's Digest (2018). Department of Finance. Jammu and Kashmir.

Hanan, E. (2015). Entrepreneurship perspective for trade and management of horticulture sector in Kashmir Himalayan valley. International Journal of Social Sciences and Management, 2(3), 284-289. doi.org/10.3126/ijssm.v2i3.12986.

Horticulture at a Glance (2018). Government of India. Ministry of Statistics, Planning and Implementation.

Khursheed, V., \& Taufeeuq, M. (2019). Spatial analysis of horticulture efficiency and fruit production concentration in Kashmir Valley. GeoJournal, 1, 1-9. doi.org/10.1007/s10708019-10043-z. 
Kumar, N., Singh, S. P., Kachroo, J., Singh, H., Kumar, C., \& Ahmed, N. (2013). Economic analysis of cost and return for basmati rice cultivation in Jammu district of $\mathrm{J} \& \mathrm{~K}$ state. International Journal of Agricultural Sciences, 9(2), 674-677.

Malhotra, S. P., \& McNeil, D. L. (2009). Economics of walnut production in India. In VI International Walnut Symposium, 861, 229-236.

Mohapatra, S., Mohapatra, U., Chandana, K. S. S., \& Mishra, R. (2018). Economic analysis of paddy production and marketing in puri, Odisha. Journal of Pharmacognosy and Phytochemistry, 7(4), 1858-1861.

Naqash, F. (2015). A value chain analysis of apple in Jammu and Kashmir (Doctoral dissertation, SKUAST Kashmir).

Qadri, B. (2018). Problems of saffron marketing in Kashmir Valley. Journal of Eco-friendly Agriculture, 13(2), 44-51.

Qammer, N. A., \& Baba, S. H. (2018). Analysis of modernized value chain of walnut in Jammu \& Kashmir. Economic Affairs, 63(1), 165-174. doi.org/10.30954/0424-2513.2018.00150.21.

Sharma, R., \& Sumbali, G. (2014). Fungal diversity associated with the commercial grades of walnut kernels sold in the markets of Jammu and Kashmir State (India). International Journal of Pharmaceutical Science Invention, 3, 50-57.

Sharma, A., \& Tungoe, B. L. (2011). Price spread and marketing efficiency in marketing of potato in the Wokha district of Nagaland. Progressive Agriculture, 11(1), 23-27.

Shigaeva, J., \& Darr, D. (2020). On the socio-economic importance of natural and planted walnut (Juglans regia L.) forests in the Silk Road countries: A systematic review. Forest Policy and Economics, 118, 102233. https://doi.org/10.1016/j.forpol.2020.102233.

Britton, T. M., Leslie, C. A., Dandekar, A. M., McGranahan, G. H., \& Caboni, E. (2009). Persian Walnut. Compendium of Transgenic Crop Plants, 285-300.

Wani, S. A., Shaheen, F. A., Baba, S. H., Naqash, F., \& Mazoor, M. (2014). Value chains for livestock products in Himalayan mountains: studies from Jammu and Kashmir. Indian Journal of Agricultural Economics, 69(902-2016-68347), 280-289. 